\title{
APPLICATION OF COMPOSITES, COMPOMERS AND GLASS-IONOMER CEMENTS IN CARIES PREVENTION ON OCCLUSAL TOOTH SURFACE
}

\author{
O. Dolić, J.Vojinović, "M. Obradović, S. Sukara, Ž. Kojić, N. Trtić \\ University of Banja Luka, Faculty of Medicine, Save Mrkalja 14, \\ Banja Luka, Republic of Srpska, B\&H
}

\begin{abstract}
Caries is more likely to occur in fissures and pits on occlusal tooth surface than on its smooth surface. Prevention of dental caries on occlusal surface is possible by applying composites, compomers and glass-ionomer cements, as methods of fissure and pit sealing, immediately after tooth eruption. The development of adhesive dentistry has enabled effective implementation of this method, which has become one of the first minimally invasive procedures. Although it is very simple and economically viable, the method of fissure and pits sealing is still rarely applied in our area. The paper outlines characteristics of materials used in the method of fissure and pits sealing and shows the state of sealing, retention of sealant on the first permanent molars in a three-year period, after the first, second and third year of fissure and pits sealing .
\end{abstract} sealing.

Keywords: caries, composites, compomers, glass-ionomer cements, fissure and pits

\section{INTRODUCTION}

Dental caries is a destructive disease of hard dental tissues. Caries and periodontal disease are the most widespread pathological processes of modern civilization, in general. Also, dental caries is the most frequent chronic disease in children [1].

Current knowledge about the local origin of disease, its pathogenesis and numerous exogenous and endogenous factors that slow down, accelerate or prevent its development, indicate a complex interaction between cariogenic microorganisms organized in dental plaque, the presence of carbohydrates, defense capacity of saliva and resistance of enamel mineral structure.

Early caries occurrence is tightly connected with occlusal morphology and is more frequent in pit and fissures than on smooth dental surface. The morphology of the occlusal surface is very complex, and the dimensions of the fissures varied not only between different types of teeth, but also in the same part of the occlusal surface of teeth. Fissures can reach deep into the occlusal surface of teeth and may show narrowing or they can vary in depth in different places. The depth of fissures ranges from 40$1220 \mu \mathrm{m}$, obliquity of fissures walls is the extent of 35 to $100^{\circ}$, and width can be $6-180 \mu \mathrm{m}$. In many studies, fissures were classified only on the basis of their morphological characteristics, as different $U$, $\mathrm{V}, \mathrm{Y} 1$ and Y2 types of fissures. Fissures are sometimes classified in relation to the depth of the gap in fissures bottom as shallow, deep and intermediate type $[2,3]$.

Since endogenous and exogenous application of fluoride cannot reduce occlusal caries completely, many studies attempted to arrive at other prophylactic measures. In 1985, Wilson put cement in the pits and fissures. After him, many researchers applied various materials in pit and fissures (silver nitrate, zinc chloride, copper amalgam, oxyphosphate cement, etc.) in order to prevent caries [4].

Finding specific prophylactic measures for prevention of occlusal dental caries is particularly topical since the year 1967 when Cueto and Buonocore introduced the process of pit and fissures sealing. Pit and fissure sealing is a specific clinical procedures that applies appropriate application of materials in order to protect the pit and fissures on occlusal surfaces from the impact of cariogenic oral environment factors. It is one of the most effective methods in preventing tooth decay. Ripple 1976, Gwinett 1976, and Simonsen 1978, Houpt et al. in 1986 and numerous other authors have improved that procedure thus contributing to a number of clinical and in vitro studies. [5,6,7,8] At the American Dental Association (ADA) meeting in 1983, it was conclu-

${ }^{*}$ Corresponding author: o.ilic@teol.net 
ded that the application of sealant is safe and effective prophylactic measure that should be an integral part of prevention program [4].

The pharmacodynamic effects of modern sea-

lant imply the following:

- There is no systemic toxicity;

- They are safe;

- They do not damage the hard and soft tissues;

- They do not disturb the occlusion;

- They prevent the effect of dental plaque on the tooth surface (pits and fissures);

- They prevent the development of cariogenic flora which is already present in pits and fissures;

- They prevent further progression of initial enamel demineralization.

\section{MATERIALS FOR PIT AND FISSURE SEALANTS}

Today, the sealants are available as composite, compomer and glass-ionomer materials.

\subsection{Composite sealants}

Composite sealants prevent oclussal caries primarily through physical obturation of pit and fissures. They do not contain active cariostatic components and their preventive role is based solely on physical isolation of fissures from oral environment to prevent the flow of nutrient substances by bacteria that are found in the deeper parts of the fissure system $[10,11]$.

In modern dentistry the first fissure sealant was the materials on the basis of BIS-GMA. They are the same structure as composite materials for restoration, but contain much less filler, to reduce their viscosity and to allow them better penetration into pit and fissures. In composite sealant color pigments can also be added for better visibility and control, as well as cariostatic substance such as fluoride. $[10,12]$.

Initiation of polymerization of the composite sealants can be chemical or photochemical. Today, chemically initiated sealants are rarely used. Serious complaints have been addressed to ultraviolet light initiated sealants. These complaints were in terms of harmful radiation to oral tissues and the low depth of light penetration through the material. These materials were succeeded by the materials where the polymerization process starts with visible light of wavelength $470 \mathrm{~nm}$. The advantages of visible light are reflected in lower light intensity, greater depth of penetration and penetration through the enamel, as well as less exposure to radiation, and less danger of the radiation consequences. The filler improvement decreased the porosity of materials and enhanced physical and mechanical properties. Photosensitive composite resins are mainly made of mono-and bifunctional photosensitive monomers and initiators, which are responsible for the beginning of chains, composed of free radicals providers $[10,11,12]$.

The clinical procedure of composite sealant retention is achieved by etching the enamel surface with acid. Acid etching is the physical-chemical process that increases the active surface of the enamel, for adhesion of composite materials. This excludes the microgaps occurrence between enamel and materials. The phosphoric acid action on enamel structure leads to the dissolution of hydroxyapatite. Along with that different acid precipitation of calcium phosphate occurs. It is considered that the time of etching enamel with $37 \%$ phosphoric acid in permanent teeth should not be longer than 30 seconds, while in primary teeth should equal between 30 and 60 seconds $[12,13,14]$.

\subsection{Composite sealants with fluoride}

In the beginning of the nineties there develops composite sealants which have the ability of releasing fluoride, as a result of the tendency to add a well-known caries protective effect of fluoride such good mechanical role of composite sealants, like physical isolation of fissures from oral environment. Composite materials have excellent mechanical properties, and fluoride should have a therapeutic and preventive effect due to the mechanism of enamel remineralization.

Composite sealants with fluorides $(2-5 \% \mathrm{NaF})$ have led to increased concentrations of fluoride in enamel and reduce enamel solubility in acids. Composite sealants with fluoride have effective mechanical barriers, enhance enamel resistance and provide remineralization process. Studies have shown that the effect of fluoride from composite materials is much weaker than the fluoride from glass ionomer sealants $[10,15,16]$.

\subsection{Compomer sealants}

Compomers are modified composite resins with polyacides and belong to the group of hybrid dental materials. Aesthetic properties of traditional composite systems in compomers combined with the properties of fluoride and adhesion of glass-ionomer cements. The level of fluoride release in compomer and composite sealants with fluoride is lower than in glass-ionomer materials [10,17]. Retention rate of compomer sealants is similar to the composite sea- 
lants. Clinical trials have shown that compomer sealants fully compete with composite sealants except for the marginal adaptation $[10,18]$.

\subsection{Glass-ionomer sealants}

Glass-ionomers are used as fissure sealants due to their chemical bond to enamel without previous etching and continuous fluoride ion release and incorporation into the surrounding mineralized enamel and dentin $[5,19]$.

The basic advantages of glass-ionomers such as the possibility of chemical bonding to enamel, the continuous release of fluoride ions from a base matrix and the incorporation of fluoride ions into the surrounding mineralized enamel and dentin were used for the production of glass-ionomer sealants. The first systematic report about glass-ionomer cements as pit and fissure sealants in 1996 stated that glass-ionomer cements did not show worse cariesprotective effect than composite sealants although they had lower retention [20].

It is necessary to provide a dry working field when using composite sealants. Glass-ionomer sealants can be an alternative to composite materials, especially when it is difficult to set composite sealant, or in wet conditions. Thanks to the hydrophilic properties, glass-ionomer cements are not as sensitive to moisture as composite materials [21]. The release of fluoride from glass-ionomer sealants provides their strong diffusing into enamel so prolonged fluoride release continues after the sealants drop out [22,23].

Some authors even recommend setting up glass-ionomers as temporary sealants to provide an adequate barrier to the penetration of microorganisms and also act as a fluoride reservoir while the conditions are met for setting up "permanent" composite sealant [24].

\section{OBJECTIVE}

The aim of this study was to examine the durability and retention of sealant on the first permanent molars in the period of three years, separately after the first, second and third year of placing sealant on teeth.

\section{MATERIAL}

Data was collected from medical records of patients who had their first permanent molars sealed between January 01, 2007 and March 01, 2010. Pati- ents, both male and female, ranged in age from 2 to 12 years. The criteria for teeth selection were intact first permanent molars that did not show any sign of caries development after a standard examination using dental probe and dental mirror by standard dental illumination. The first permanent molars that have not erupted completely were excluded.

During the period of the research, the three dentists placed a total of 236 sealants in first permanent molars, all meeting the research inclusion criteria (Table 1).

Table 1. Sealed teeth by the year of sealing

\begin{tabular}{|c|c|c|c|c|}
\hline teeth & $\begin{array}{c}\text { year } \\
2007\end{array}$ & $\begin{array}{c}\text { year } \\
2008\end{array}$ & $\begin{array}{c}\text { year } \\
2009\end{array}$ & total \\
\hline 16 & 24 & 18 & 15 & 57 \\
\hline 26 & 18 & 21 & 14 & 53 \\
\hline 36 & 26 & 22 & 10 & 58 \\
\hline 46 & 27 & 27 & 14 & 68 \\
\hline total & 95 & 88 & 53 & 236 \\
\hline
\end{tabular}

Optimal field isolation using the rubber dam is often not possible in children, so cotton roll isolation and suction were used for sealants to ensure a moisture free occlusal surface. Ultra-Etch $(35 \%$ phosphoric acid gel) was applied to air-dried tooth surfaces for 30 seconds. After etching, the acid was rinsed with water for 30 seconds and the teeth air dried for 15 seconds. In all cases Fisurit-F (VocoGermany) pit and fissure sealant was applied and light cured for 30 seconds. After that retention and occlusion were checked and polishing and local applications of high concentrations fluorides were done.

Sealant integrity after the first, the second and the third year was recorded as: A - intact, the tooth remains under observation; B - sealant partly or completely absent with no caries; the tooth needs to be resealed; C - caries detected under or around the sealant; the tooth needs to be restored- the first class of filling; D - caries detected under or around the sealant; the tooth needs to be restored- the second class of filling.

\section{RESULTS}

The results of sealant condition in the first permanent molars over the three years period are shown in Table 2 and Figure 1.

A total number of 236 sealants were analyzed. Over the 3-year period, 204(86.44\%) sealed first permanent molars were intact, $10(4.24 \%)$ were resealed, $14(5.93 \%)$ were restored with one surface the first class of filling and $8(3.39 \%)$ were restored with the second class of filling. In other words, $90.68 \%$ of 
teeth were caries free (intact and resealed). After three years there was no statistically significant difference of treatments of failed sealants between groups of teeth. Also, there was no statistically significant difference after the first and the second year.
The annual distribution of repeated treatments in first permanent molars is presented in Figure 2 and in Table 3.

Table 2. Sealant condition after three years.

\begin{tabular}{|c|c|c|c|c|c|c|c|c|c|c|}
\hline & \multicolumn{2}{|c|}{ A-intact } & \multicolumn{2}{c|}{ B-resealed } & \multicolumn{2}{c|}{$\begin{array}{c}\text { C-restored (the } \\
\text { first class of } \\
\text { feeling) }\end{array}$} & \multicolumn{2}{c|}{$\begin{array}{c}\text { D-restored (the } \\
\text { first class of } \\
\text { feeling) }\end{array}$} & \multicolumn{2}{c|}{$\begin{array}{c}\text { Caries Free (intact and } \\
\text { resealed)A+B }\end{array}$} \\
\hline teeth & $\mathrm{n}$ & $\%$ & $\mathrm{n}$ & $\%$ & $\mathrm{n}$ & $\%$ & $\mathrm{n}$ & $\%$ & $\mathrm{n}$ & $\%$ \\
\hline 16 & 45 & 78,95 & 3 & 5,26 & 6 & 10,53 & 3 & 5,26 & 48 & 84,21 \\
\hline 26 & 47 & 88,68 & 2 & 3,77 & 2 & 3,77 & 2 & 3,77 & 49 & 92,45 \\
\hline 36 & 51 & 87,93 & 2 & 3,45 & 3 & 5,17 & 2 & 3,45 & 53 & 91,38 \\
\hline 46 & 61 & 89,71 & 3 & 4,41 & 3 & 4,41 & 1 & 1,47 & 64 & 94,12 \\
\hline total & 204 & 86,44 & 10 & 4,24 & 14 & 5,93 & 8 & 3,39 & 214 & 90,68 \\
\hline
\end{tabular}

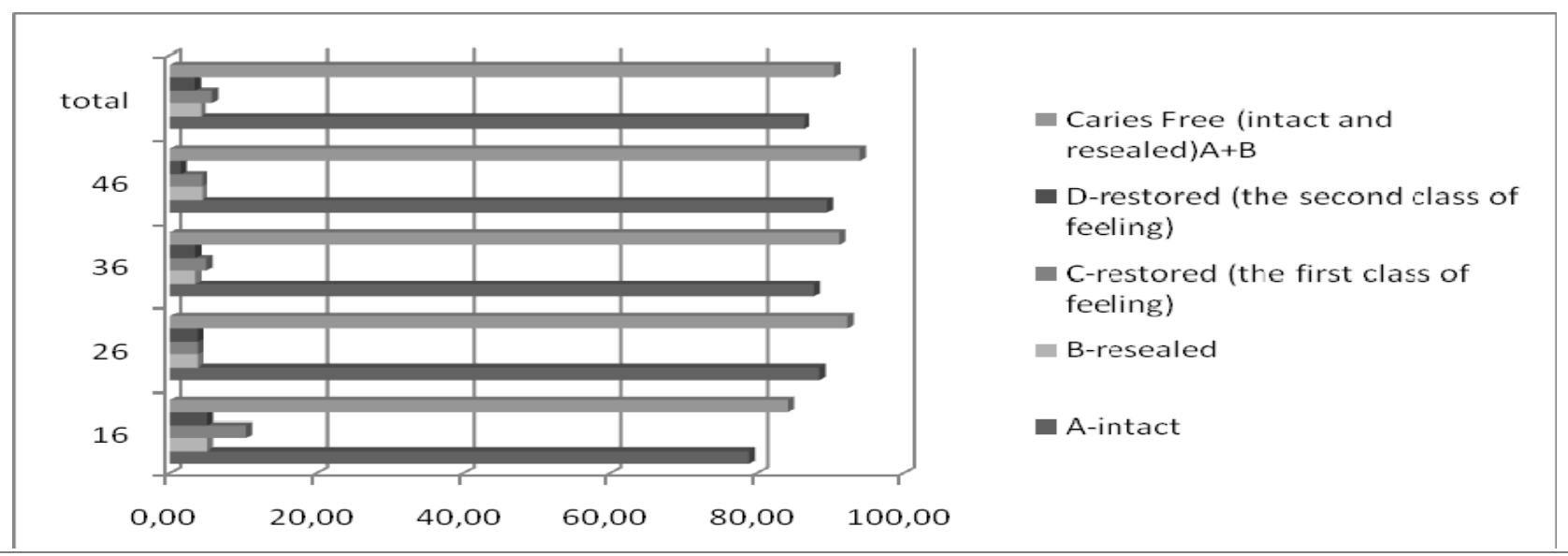

Figure 1. Sealant condition after three years

There was a $4.24 \%$ sealant failure rate in the first year, in total. $3.51 \%$ of upper right first permanent molars (16) were resealed, $3.51 \%$ of teeth were restored with the first class of filling, and $1.75 \%$ were restored with the second class of filling. $1.89 \%$ of upper left first permanent molars (26) were resealed, there were no restored teeth. $1.72 \%$ of lower left first permanent molars (36) were resealed, $1.72 \%$ were restored with the first class of filling and $1.72 \%$ was restored with the second class of filling. $1.47 \%$ of lower right first permanent molars (46) were resealed, there were no restored teeth.

There was a $5.09 \%$ sealant failure rate in the second year of study. There were no resealed upper right first permanent molars (16). Also, there were no restored upper right first permanent molars (16) with the second class of filling and $5.26 \%$ were restored with the first class of filling. $1.89 \%$ of upper left first permanent molars (26) were resealed, $1.89 \%$ were restored with the first class of filling, and $3.77 \%$ were restored with the second class of filling. There were no resealed lower left first permanent molars (36), $1.72 \%$ were restored with the first class of filling and there were no restored teeth with the second class of filling . $1.47 \%$ of lower right first permanent molars (46) were resealed, $2.94 \%$ were restored with the first class of filling, and $1.47 \%$ were restored with the second class of filling.

There was a $4.23 \%$ sealant failure rate in the third year of study. $1.75 \%$ of upper right first permanent molars (16) were resealed, $1.75 \%$ were restored with the first class of filling and $3.51 \%$ were restored with the second class of filling. There were no resealed upper left first permanent molars (26), $1.89 \%$ were restored with the first class of filling and there were no restored teeth with the second class of filling. $1.72 \%$ of lower left first permanent molars (36) were resealed, $1.72 \%$ were restored with the first class of filling and $1.72 \%$ were restored with the second class of filling. $1.47 \%$ of lower right 
first permanent molars (46) were resealed, $1.47 \%$ were restored with the first class of filling there were

Table 3. The annual distribution of repeated treatments in first permanent molars

\begin{tabular}{|c|c|c|c|c|c|c|c|c|c|c|c|c|c|c|c|c|c|c|}
\hline \multirow[b]{3}{*}{ зуби } & \multicolumn{6}{|c|}{ the first year } & \multicolumn{6}{|c|}{ the second year } & \multicolumn{6}{|c|}{ the third year } \\
\hline & \multicolumn{2}{|c|}{$\begin{array}{c}\text { B- } \\
\text { resealed }\end{array}$} & \multicolumn{2}{|c|}{$\begin{array}{l}\text { C- } \\
\text { restored } \\
\text { (the first } \\
\text { class of } \\
\text { feeling) }\end{array}$} & \multicolumn{2}{|c|}{$\begin{array}{l}\text { D- } \\
\text { restored } \\
\text { (the } \\
\text { second } \\
\text { class of } \\
\text { feeling) }\end{array}$} & \multicolumn{2}{|c|}{$\begin{array}{c}\text { B- } \\
\text { resealed }\end{array}$} & \multicolumn{2}{|c|}{$\begin{array}{l}\text { C- } \\
\text { restored } \\
\text { (the first } \\
\text { class of } \\
\text { feeling) }\end{array}$} & \multicolumn{2}{|c|}{$\begin{array}{l}\text { D- } \\
\text { restored } \\
\text { (the } \\
\text { second } \\
\text { class of } \\
\text { feeling) }\end{array}$} & \multicolumn{2}{|c|}{$\begin{array}{c}\text { B- } \\
\text { resealed }\end{array}$} & \multicolumn{2}{|c|}{$\begin{array}{l}\text { C- } \\
\text { restored } \\
\text { (the first } \\
\text { class of } \\
\text { feeling) }\end{array}$} & \multicolumn{2}{|c|}{$\begin{array}{c}\text { D- } \\
\text { restored } \\
\text { (the } \\
\text { second } \\
\text { class of } \\
\text { feeling) }\end{array}$} \\
\hline & $\mathrm{n}$ & $\%$ & $\mathrm{n}$ & $\%$ & $\mathrm{n}$ & $\%$ & $\mathrm{n}$ & $\%$ & $\mathrm{n}$ & $\%$ & $\mathrm{n}$ & $\%$ & $\mathrm{n}$ & $\%$ & $\mathrm{n}$ & $\%$ & $\mathrm{n}$ & $\%$ \\
\hline 16 & 2 & 3,51 & 2 & 3,51 & 1 & 1,75 & 0 & 0,00 & 3 & 5,26 & 0 & 0,00 & 1 & 1,75 & 1 & 1,75 & 2 & 3,51 \\
\hline 26 & 1 & 1,89 & 0 & 0,00 & 0 & 0,00 & 1 & 1,89 & 1 & 1,89 & 2 & 3,77 & 0 & 0,00 & 1 & 1,89 & 0 & 0,00 \\
\hline 36 & 1 & 1,72 & 1 & 1,72 & 1 & 1,72 & 0 & 0,00 & 1 & 1,72 & 0 & 0,00 & 1 & 1,72 & 1 & 1,72 & 1 & 1,72 \\
\hline 46 & 1 & 1,47 & 0 & 0,00 & 0 & 0,00 & 1 & 1,47 & 2 & 2,94 & 1 & 1,47 & 1 & 1,47 & 1 & 1,47 & 0 & 0,00 \\
\hline total & 5 & 2,12 & 3 & 1,27 & 2 & 0,85 & 2 & 0,85 & 7 & 2,97 & 3 & 1,27 & 3 & 1,27 & 4 & 1,69 & 3 & 1,27 \\
\hline
\end{tabular}

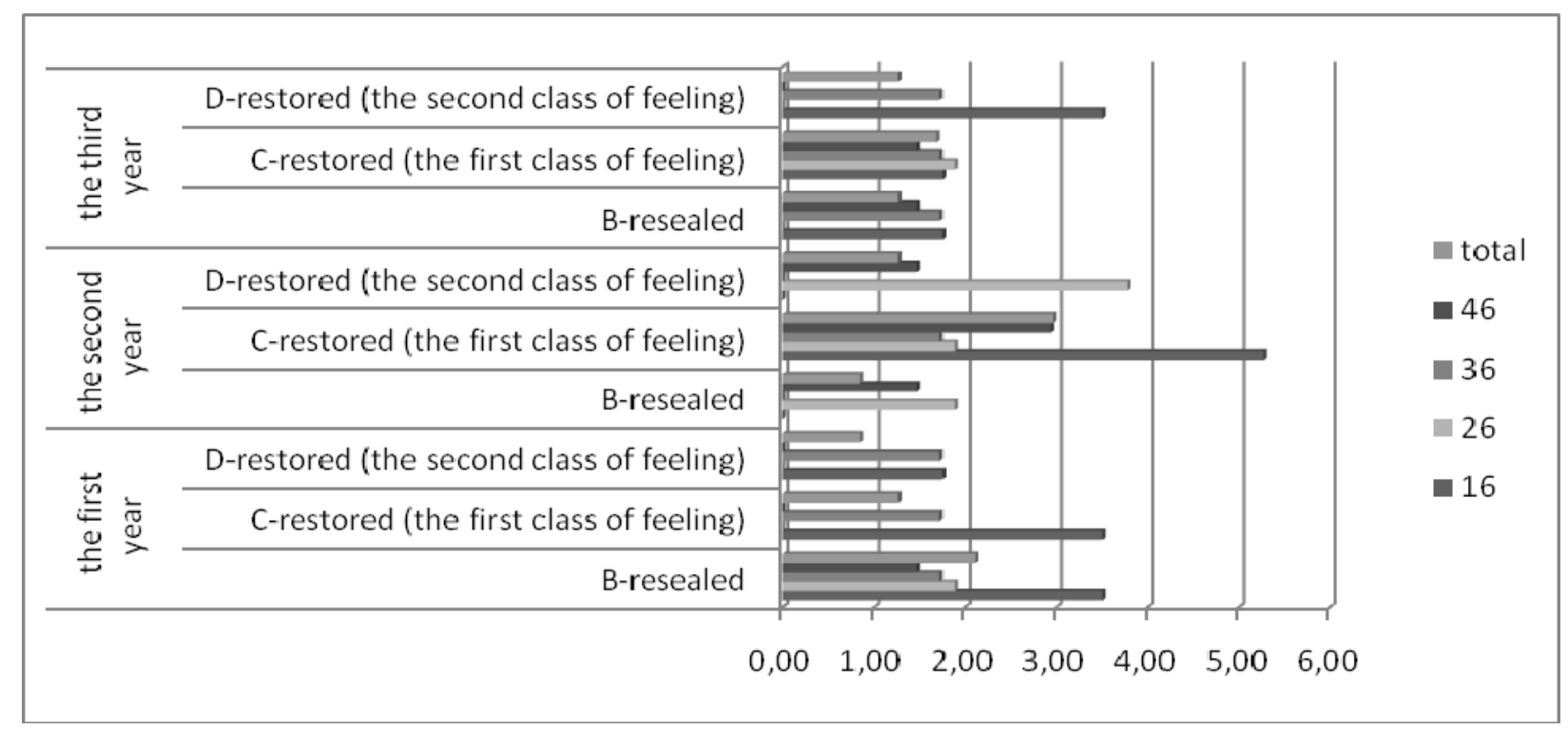

Figure 2. The annual distribution of repeated treatments in first permanent molars

\section{DISCUSSION}

Preventive method of sealing pit and fissures is an important procedure because the specific fissure morphology gives condition that caries in pit and fissures can not be avoided, in spite of balanced diet, daily hygiene, fluoridation and regular dental checkups.

When applying sealants it is necessary to have a close contact between fissures and sealants. This requires checking-up of sealants and possibly resealing so as to avoid the caries development.

Our study showed that the upper right first permanent molars (16) often require resealing. Also the upper right first permanent molar teeth were the teeth most likely to require restoration. This was consistent with other research findings where it is in- dicated that the upper molars are notorious for sealant loss $[25,26]$. A possible explanation is that it is difficult to set up the sealant and cure it on time, due to the posterior position in the mouth, an imperfect lighting system for curing. Furthermore, the dentists in this study were right-handed and thus lingual grooves of teeth at the right side were not as easily seen. Most of the children were right-handed and we could assume that they brushed their teeth better on the left side of their mouths.

The highest sealant failure rate was after the second year of sealing. According to Whitehurst and Sony, the biggest loss of sealant occurred during the first 6 months, and only $18 \%$ of first and second permanent molars were completely sealed after the first year [27]. Also, Stephen et al. field study indicates 
that only 12 of nearly 400 teeth remained completely sealed after the first year [25].

A high sealant retention rate of $76-85 \%$ after 10 months was observed by Shashikiran et al, which could be attributed to their use of rubber dam isolation and sealant reapplication [26].

Considering possible reasons for failure of resin sealant, Anson et al. listed poor placement technique (inadequate moisture control, not sealing all pits/fissures, inadequate etching, inadequate rinsing and drying, and insufficient curing time); material wear; and finally, failure due to a combination of these factors [27]. Other factors, according to some authors, which influence sealant retention, include the position of the tooth in the mouth, the skill of the dentist, and the age of the patient [25].

\section{CONCLUSION}

Our research, as well as numerous other studies, has shown that pit and fissure sealants were retained for a longer period. There was only a small sealant failure rate and developed carious lesions on occlusal surfaces after sealant failure, thus illustrating the necessity of sealing the teeth, as well as important caries preventive measures.

\section{REFERENCES}

[1] U.S. Department of Health and Human Services. Oral health in America: a report of the Surgeon General. Rockville, MD: HHS, National Institutes of Health. National Institute of Dental and Craniofacial Research, 2000.

[2] H. E. Schröder, Oral Structurbiologie. G. Thime Verlag, Sttudgart, New York 1982, 20-159.

[3] M. Rohr, O. F. Makinson, M. F. Burrow, Pits and fissures: morphology, ASDC J Dent Child. 58 (1991) 97-103.

[4] NIH Consensus Development Conference Summary: Dental sealants in the prevention of tooth decay, British Dental Journal 3 (1984) 45-53.

[5] J. Mejare, J. A. Mjor, Glass ionomer and resin based fissure sealants: a clinical study, Scand. J. Dent.Res. 7 (1990) 345-50.

[6] W. H. Liebenberg, The fissure sealant imphasse, Quint. Int, 25 (1994) 11-19.

[7] M. L. Swartz, R.W. Phillips, H. E. Clark, Long term fluoride release from glass ionomer cement, J. Dent. Res. 63 (1984) 158-60.

[8] S. C. Temin, Z. Csuros, Long term fluoride release from composite restorative, Dent. Mater. 4 (1988) 184-6.
[9] T. L. Morphis, K. J. Toumba, N. A. Lygidakis, Fluoride pit and fissure sealant: a review, Int J. Paediatr Dent. 10 (2000) 90-98.

[10] R. J. Simonsen, Pit and fissure sealant: review of the literature, Pediatr Dent. 24 (2002) 393-414.

[11] N. O. Harris, F. Garcia-Godoy, Primary preventive dentistry, $6^{\text {th }}$ edition. Pearson Prentice Hall 2004.

[12] J. Walker, K. Floyd, J. Jacobsen, J. R. Pinkham, The effectiveness of preventive resin restorations in pediatric patients, J. Dent. Child. 63 (1996) 338-340.

[13] D. J. Manton. L. B. Messer, Pit and fissure sealants: another major cornerstone in preventive dentistry, Aaust Dent. J. 40 (1995) 22-29.

[14] E. G. Feldens, C. A. Feldens, F. B. de Araujo, M. A. Souza, Invasive technique of pit and fissure sealants in primary molars: a SEM study, J Clin Paediatr Dent. 18 (1994) 187-190.

[15] I. Ilijin, D. Karajović, Z. Vulćević, Fluoride release from various dental materials, Int. Dent. Jour. Oct. 46, 5 (1996) 65.

[16] D. V. Salar, F. Garcia-Godoy, C. M. Flaitz, M. J. Hicks. Potential inhibition of demineralization in vitro by fluoride-releasing sealants, J. Am. Dent. Assoc. 138 (2007) 502-506.

[17] A. J. Shaw, T. Carrick, J. F. McCabe, Fluoride release from glass-ionomer and compomer restorative materials: 6-months data. J. Dent. 26 (1998) 355-359.

[18] R. M. Puppin-Rontani, M. E. BaglioniGouvea, M. F. deGoes, F. Garcia-Godoy, Compomer as a pit and fissure sealant: effectiveness and retention after 24 months, J. Dent. Child. 73 (2006) 31-36.

[19] R. C. Overbo, M. Raadal, Microleakage in fissures sealed with resin or glas ionomer cement, Scand. J. Den.t Res. 98 (1990) 66-68.

[20] R. J. Simonsen, Glass ionomer as fissure sealant- a critical review, J. Public Health Dent. 56 (1996) 146-149.

[21] M. Ganesh, S. Tandon, Clinical evaluation of FUJI VII sealant material, J. Clin Pediatr. Dent. 31 (2006) 52-57.

[22] H. Komatsu, H. Shimokobu, Matsui and all. Enamel fluoride uptake from glass-ionomer cement designed for sealent, Japanese J. Conserv. Dent. 32 (1989) 688-92.

[23] K. Oshima, T. Ikea, J Kaneshige and all., The change of fluoride concentration in enamel after removal of glass-ionomer cement in vivo, Japanese $\mathrm{J}$. Conserv. Dent. 32 (1989) 986-91.

[24] J. Wanuck, S. Antonson, D. E. Antonson and B. De Santis. Retention of surface protectant se- 
alants on contaminated enamel surface. IADR, Baltimore, Maryland, USA. March 2005, Abstract 1729.

[25] J. T. Cline, L. B. Messer, Long term retention of sealants applied by inexperienced operators in Minneapolis. Community Dent Oral Epidemiol. 7, 4 (1979) 206-12.

[26] L. K. Wendt, G. Koch, D. Birkhed, On the retention and effectiveness of fissure sealant in permanent molars after 15-20 years: a cohort study, Community Dent Oral Epidemiol. 29, 4 (2001), $302-7$.
[27] L. W. Ripa, Occlusal sealants: Rationale and review of clinical trials. Int, Dent. J. 30 (1980) 127-33.

[28] N. D. Shashikiran, V. V. Subbareddy, A. Deshpande, A clinical comparison of visible light activated unfilled, fluoride and non-fluoride containing and filled fluoride containing pit and fissure sealants, J. Cons. Dent. 7 (2004) 70-6.

[29] L. B. Messer, H. Calache, M.V. Morgan, The retention of pit and fissure sealants placed in primary school children by Dental Health Services, Victoria. Aust. Dent. J. 42 (1997) 233-9.

$\operatorname{son}$

\section{ПРИМЈЕНА КОМПОЗИТА, КОМПОМЕРА И ГЛАС-ЈОНОМЕР ЦЕМЕНАТА У ПРЕВЕНЦИЈИ КАРИЈЕСА ОКЛУЗАЛНИХ ПОВРШИНА ЗУБА}

Сажетак: Каријес се чешће јавља у фисурама и јамицама оклузалних површина зуба него на његовим глатким површинама. Превенција каријеса оклузалних површина зуба је могућа примјеном композита, компомера и глас-јономер цемената, односно поступком заливања фисура и јамица, непосредно након ницања зуба. Развој адхезивне стоматологије омогућио је ефикасну примјену ове методе, чиме је постала једна од првих минимално инвазивних процедура. Иако је веома једноставна и економски исплатива, метода заливања фисура и јамица се на нашим просторима још увијек ријетко примјењује. У овом раду описане су особине материјала који се користе у поступку заливања јамица и фисура и приказано је стање заливених фисура, односно ретенција заливача на првим сталним моларима у периоду од три године, и то након прве, друге и треће године од постављања заливача на зубе.

Кључне ријечи: каријес, композити, компомери, глас-јономер цементи, заливање фисура и јамица. 